\title{
REEF ENVIRONMENTS OF MURCIÉLAGO ISLANDS AND SANTA ELENA PENINSULA, GUANACASTE CONSERVATION AREA, COSTA RICAN PACIFIC
}

\author{
Juan José Alvarado,,${ }^{* * * * *}$, Juan Carlos Azofeifa-Solano*, \\ Andrés Beita-Jiménez, Jorge Cortés ${ }^{* * * * * * *}$, Sebastián Mena*, \\ Carolina Salas-Moya, Cindy Fernández-García ${ }^{* * *, *}$
}

\section{Abstract}

The ecology of the marine environments of the Murciélago Islands and the Santa Elena Peninsula have been studied little despite their high biodiversity. This area is influenced by a coastal upwelling. In 2014, 2016 and 2018, the region was visited to assess the composition and diversity of its reef environments. Bottom coverage, macroinvertebrate diversity and abundance, and reef fish biomass were quantified. The substrate was dominated by turf and crustose calcareous algae. Live coral coverage has decreased compared to previous reports for the area. Sea urchins were the macroinvertebrates with the highest densities, while species of commercial interest presented low densities, this may suggest some degree of fishing pressure. 84 reef fish species were identified, making the islands area with the greatest diversity of reef fish in the North Pacific of Costa Rica. Coral biotopes in this region are key to the conservation of connectivity between reef areas due to their high diversity.

KeYwOrds: Coastal ecosystems, continental island, coral reefs, rocky reefs, seaweed.

\section{AMBIENTES ARRECIFALES DE LAS ISLAS MURCIÉLAGO Y LA PENÍNSULA DE SANTA ELENA, ÁREA DE CONSERVACIÓN GUANACASTE, PACÍFICO DE COSTA RICA}

\section{RESUMEN}

Las Islas Murciélago y la península de Santa Elena han sido ambientes marinos poco estudiados a pesar de la alta biodiversidad de sus ecosistemas. Esta zona está influenciada por un afloramiento costero. En el 2014, 2016 y 2018 se visitó la región para evaluar la composición y diversidad de sus ambientes arrecifales. Se cuantificó la cobertura del fondo, la diversidad y abundancia de macroinvertebrados y la biomasa de peces arrecifales. El sustrato estuvo dominado por tapetes algales (turf) y algas calcáreas costrosas. La cobertura de coral vivo se ha reducido con lo previamente reportado para la zona. Los erizos de mar tuvieron las densidades más altas entre los macroinvertebrados, mientras que especies de interés comercial presentaron bajas densidades, lo que sugiere cierta presión pesquera. Se observaron 84 especies de peces arrecifales, lo que hace de esta área una de las mayores diversidades del Pacífico norte de Costa Rica, esto puede atribuirse a la presencia de áreas marinas protegidas. Los biotopos coralinos de esta región son claves para la conservación de la conectividad entre zonas arrecifales, debido a su alta diversidad.

Palabras Clave: ecosistemas costeros, islas continentales, arrecifes de coral, arrecifes rocosos, algas. 


\section{INTRODUCTION}

The Murciélago Islands, Guanacaste Conservation Area (ACG, by its Spanish acronym), are located in North Pacific of Costa Rica. The oldest scientific references to the Murciélago Islands are from the Templeton Crocker expedition of the California Academy of Science (Crocker 1933) and the Zaca expedition of the New York Zoological Society to the Eastern Pacific (Beebe 1938), which visited the islands and collected specimens and contributed to the knowledge of Costa Rican marine diversity. Since the mid-1990s, Costa Rican expeditions have frequented the islands to record the region's marine biodiversity, reporting 594 species with a focus on mollusks, crustaceans, and fishes (Cortés 2014, 2017). In 2015, the BioMar-ACG project was launched and recorded upwards of 1097 species, including 50 potentially new species, thus increasing the known biodiversity of the ACG to 1453 species (Cortés and Joyce 2020).

The coral reefs of the Murciélago Islands were first described 20 years ago (Cortés 1996-1997). Later, the impact of the 1997-1998 El Niño Event on these reefs was recorded (Jiménez et al. 2001), the coral species and reefs descriptions were reviewed (Cortés and Jiménez 2003), and aquarium related extraction of the populations of the Cortez rainbow wrasse (Thalassoma lucasanum) was studied with a proposal for sustainable management (McCauley et al. 2008). More recently, a detailed description of coral ecosystems was provided for the Murciélago Islands and three bays on the Santa Elena Peninsula (Playa Blanca, Santa Elena, and Cuajiniquil) between 2004 and 2008, with records of 21 coral ecosystems (nine coral reefs), 21 scleractinian coral species, with a mean live coral cover of $47.4 \pm 29.4 \%$ in the coral reefs and $30.2 \pm 21.0 \%$ in the coral communities, accounting for a total of 24480 $\mathrm{m}^{2}$ (Bassey-Fallas 2010).

These islands have been considered one of the most important reef areas in Costa Rica (Cortés 1996-1997; Cortés and Jiménez, 2003; Cortés et al. 2010). During the last decade they have been degraded by natural and anthropogenic impacts that threaten its biodiversity and ecological stability (Alvarado et al. 2018). Our study quantifies the composition and diversity of reef bottom substrates, macroinvertebrates, and fishes. These results are compared with historical data from the region with the aim of identifying possible drivers of these changes over time.

* Centro de Investigación en Ciencias del Mar y Limnología, Universidad de Costa Rica; 2060-1000 San Pedro de Montes de Oca, Costa Rica; juan.alvarado@ucr.ac.cr; juan.azofeifa@ucr. ac.cr; jorge.cortes@ucr.ac.cr; sebas.menago@gmail.com; caro.salasm@gmail.com.

Oca, Costa Rica.
$* * *$ Centro de Investigación en Biodiversidad y Ecología Tropical, Universidad de Costa Rica; 2060-1000 San Pedro de Montes de Oca, Costa Rica.

- Center for Fisheries Ecosystems Research, Fisheries and Marine Institute, Memorial University of Newfoundland, Canada; abeitaj@gmail.com.

- Herbarios Universidad de Costa Rica; 2060-1000 San Pedro de Montes de Oca, Costa Rica; cindy.fernandezgarcia@ucr.ac.cr. 


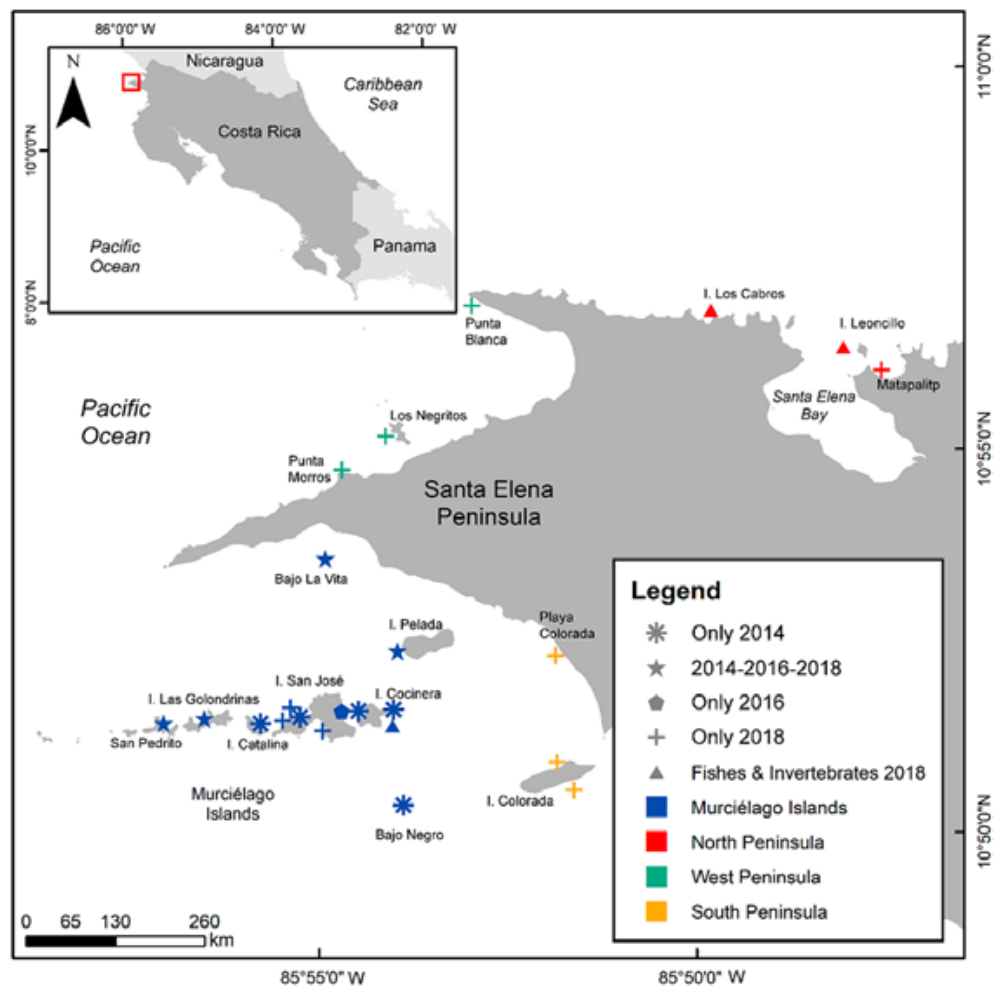

Figure 1. Map showing sites of sampling localities, methods and years, in the Costa Rican North Pacific.

\section{MATERIALS AND METHODS}

\section{STUDY AREA}

The Murciélago Islands (MI) and Santa Elena Peninsula (SE) are located on the western side of the ACG on the Costa Rican North Pacific coast (figure 1). The marine environments are included within the $430 \mathrm{~km}^{2}$ of the ACG's Marine Sector. The islands (five main islands and at least ten islets) are $5 \mathrm{~km}$ off the coast of the peninsula, are of volcanic origin as evidenced by the presence of columnar, pad and massive basalts, with an estimated age of 109 million years (Cretaceous) (Hauff et al. 2000; Denyer et al. 2005; Denyer 2019). The peninsula is made up of a sequence of alkaline basalts, radiolarite, and polymictic gaps from around the Jurassic-Cretaceous (Denyer et al. 2005; Denyer and Gazel 2009; Denyer 2019).

The North Pacific of Costa Rica is subjected to a strong seasonality, with a dry season from December to April, a first rainy season from May to June and a second from August to October. During the dry season, the influence of northeastern 
trade winds increases, causing a tropical seasonal upwelling, and exposing shallow coastal habitats to cold, nutrient-rich waters (Alfaro and Cortés 2012; Cortés et al. 2014; Lizano and Alfaro 2014). A variety of forests, meadows, shrubs, cacti, and succulents dominate terrestrial foliage on MI, while SE is covered by a tropical dry forest that extends from the mountains to the coastline (Janzen 1988).

\section{SAMPLING}

The sampling of reef ecosystems was carried out in 2014 (June 18-20; 26 transects), 2016 (July 27-28; 14 transects), and 2018 (April 21-May 1; 38 transects). Sampling was always carried out between the upwelling and rainy seasons for improved navigation and visibility underwater. Surveys of the MI were conducted at nine sites in 2014, five in 2016 and six in 2018. Seven sites were surveyed at SE in 2018. (figure 1). Due to sea conditions not all sites could be re-surveyed.

We estimated diversity and abundance of reef bottom substrates (diversity and cover), conspicuous macroinvertebrates $(>2.5 \mathrm{~cm})$, and fishes inhabiting the reef (diversity and density), following methods described by Alvarado et al. (2015, 2018). To quantify diversity and abundance of these three reef components, we used three $10 \mathrm{~m}$ transects along the reef, parallel to the coast, and between $6 \mathrm{~m}$ and $15 \mathrm{~m}$ depth. The transects were separated by $10 \mathrm{~m}$.

At each transect, a $1 \mathrm{~m}^{2}$ quadrat subdivided in 100 quadrats of $0.01 \mathrm{~m}^{2}$ each was placed successively 10 times along the transect to quantify the area occupied by each substrate taxa to the lowest identifiable taxonomic level. The reef bottom categories were: live coral, dead coral, bleached coral, macroalgae (more than $6 \mathrm{~cm}$ ), turf (less than $6 \mathrm{~cm}$ ), crustose calcareous algae (CCA), other crustose algae, sponges and "others" (such as sea squirts, sea anemones, bryozoans, polychaetes and barnacles).

Belt transects of $10 \mathrm{~m}$ length $\times 2 \mathrm{~m}$ width, centered in the same transects used for the reef bottom quadrats, were used to quantify the population densities of conspicuous macroinvertebrates $(>2.5 \mathrm{~cm})$, including benthic shelled gastropods, nudibranchs, octopuses, bivalves, holothuroids, asteroids, echinoids and some decapods (spiny lobsters and large conspicuous crabs).

Tunnel transects of $10 \mathrm{~m}$ length $\times 5 \mathrm{~m}$ width $\times 5 \mathrm{~m}$ height, centered in the same transects used for reef bottom and macroinvertebrates, were used to quantify densities of reef fishes, identify, count and estimate the sizes of fishes encountered within the tunnel transect. The fish census was carried out prior to any other monitoring of the bottom or counting of invertebrates, in order not to modify the behavior of the reef fish and to have a better appreciation of the diversity of these organisms. The diver who carried out the fish census dives at a constant speed ahead of the rest of the work team, with adequate buoyancy management, without making sudden movements that could disturb the ichthyofauna. The sizes of fish were classified by categories $(<5 \mathrm{~cm}, 5-10,10-15,15-20,20-25,25-50,50-100,100$ $150,150-200,200-250,250-300 \mathrm{~cm})$. A trophic group classification was assigned to the reef fishes according to Quimbayo et al. (2017). 
We used non-metric multidimensional scaling (nMDS) to determine similarities between sampled localities considering reef bottom cover, macroinvertebrate density, and fish biomass, using the Bray-Curtis index (Clarke and Gorley 2006). Data were standardized and square root-transformed for reef bottom, and fourth root-transformed for macroinvertebrates and fishes. Localities were grouped by sites around MI and SE: North Peninsula, West Peninsula, South Peninsula and Murciélago Islands (figure 1). We used one-way Analysis of Similarities (ANOSIM) to determine differences among localities considering as factors: site (North Peninsula, West Peninsula, South Peninsula and Murciélago Islands) and sampling year (2014, 2016 and 2018). A test of Similarity Percentages (SIMPER) was used to determine the trophic groups of fish contributed the most to similarities between sampling years. All the statistical analyses were performed using PRIMER ${ }^{\oplus} 7$.

\section{RESULTS}

\section{REEF BOTTOM COVER}

Overall, the dominate substrate by localities and years was turf algae, with an average cover ( \pm standard error) of $38.5 \pm 5.3 \%$ (with a maximum in San Pedrito during 2014 with $82.0 \%)$, followed by CCA (12.9 $\pm 3.7 \%)$, live coral (2.6 $\pm 0.8 \%)$ and macroalgae $(1.3 \pm 0.4 \%)$ (figure 2$)$. The other substrate categories such as sponges, crustose algae, barnacles, and sea squirts, comprised less than $1 \%$ of the reef floor coverage.

In this region we found some isolated coral communities built mainly by the coral Pavona gigantea, which is not commonly observed in other regions of the country. Also, in places like Colorada Island, we found Sargassum forests, where algae can reach 20 to $30 \mathrm{~cm}$ high. These forests are unique in the Costa Rican Pacific coast.

The results of the ANOSIM supported five groups of localities from the reef bottom cover data (figure 2). Group I only included Bajo Negro, with the highest CCA (89.00\%). Group II included three localities sampled during 2018 (including MI and Western SE), where turf cover was low to moderate when compared with other localities, ranging between $1.34 \%$ and $37.26 \%$, CCA coverage ranged between $2.33 \%$ and $26.72 \%$, and live coral coverage was between $0.23 \%$ and $4.70 \%$. Group III included Matapalito 2018 and south side of Colorada Island 2018, where sand cover was highest, $12.69 \%$ and $29.45 \%$, respectively. Matapalito also had the highest live coral cover among localities (20.31\%). Group IV included all localities sampled during 2014 and Isla Golondrina 2016, with moderate sand and CCA cover, and high to moderate turf cover. Group V was made up of localities with high turf cover sampled during the three years (figure 2). 


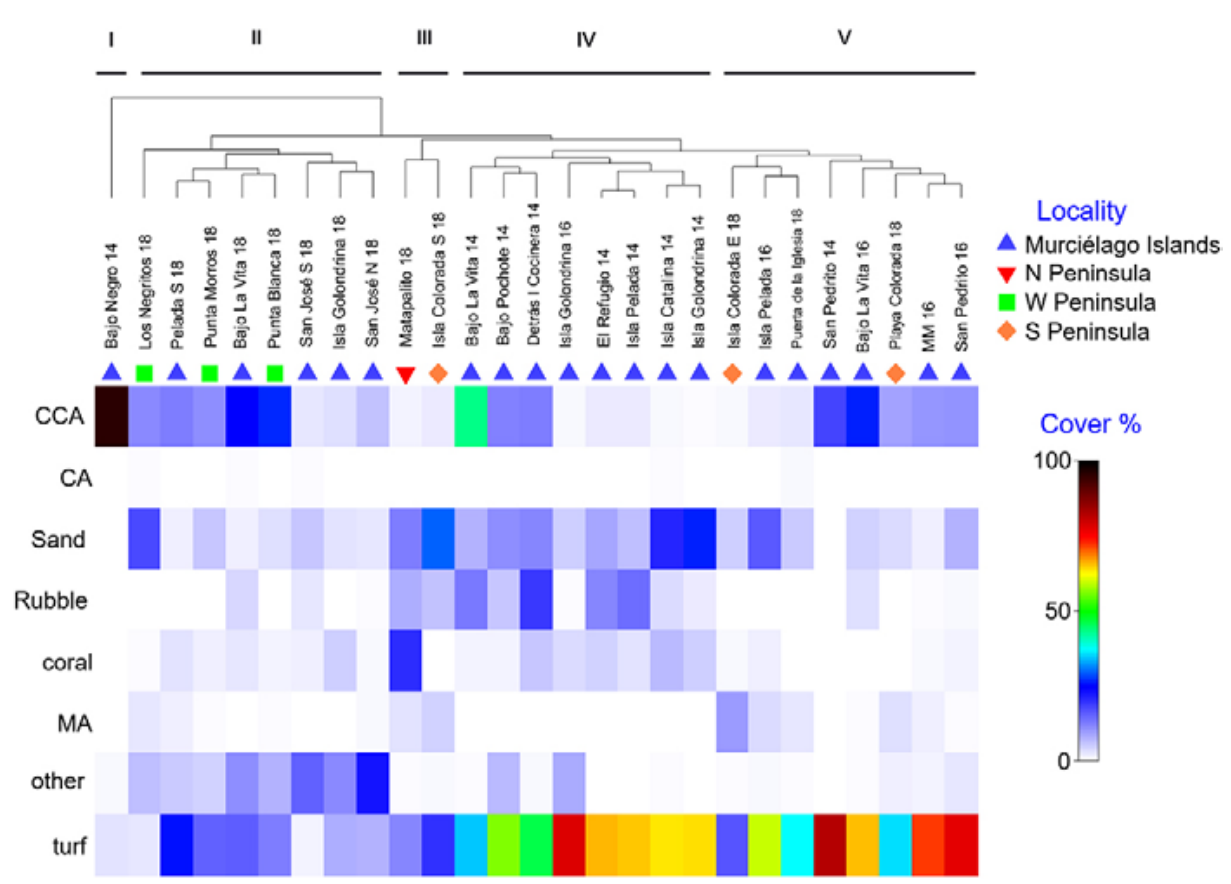

Figure 2. Similarities among localities (see fig. 1) considering the cover of the reef floor by categories of benthic organisms in Murciélago Islands and Santa Elena Peninsula, based on a Bray-Curtis index. CCA: crustose calcareous algae;

CA: crustose algae; MA: macroalgae.

\section{Macroinvertebrates}

The highest density of invertebrates was found at Bajo La Vita 2016 (23.2 ind $\left.\cdot \mathrm{m}^{-2}\right)$, while the lowest occurred at San Pedrito Island in $2018\left(1.14 \mathrm{ind} \cdot \mathrm{m}^{-2}\right)$. Echinoids were the macroinvertebrates with the highest mean densities $( \pm$ standard deviation) $2.98 \pm 1.66 \mathrm{ind} \cdot \mathrm{m}^{-2}$ (max: 6.58; min: 0.32 ), while other groups had mean densities lower than 1.00 ind $\cdot \mathrm{m}^{-2}$ (bivalves: $0.06 \pm 0.05$ ind $\cdot \mathrm{m}^{-2}$; decapods: $0.34 \pm$ 0.45 ind $\cdot \mathrm{m}^{-2}$; asteroids: $0.25 \pm 1.05$ ind $\cdot \mathrm{m}^{-2}$; nudibranchs: $0.06 \pm 0.17$ ind $\cdot \mathrm{m}^{-2}$; holothuroid: $0.46 \pm 1.11 \mathrm{ind} \cdot \mathrm{m}^{-2}$; octopuses: $0.01 \pm 0.02 \mathrm{ind} \cdot \mathrm{m}^{-2}$ ).

The results of the ANOSIM for macroinvertebrates showed a highly heterogeneous composition between localities, and conspicuous groups were not observed (figure 3A). However, there was a subgroup from MI that was not similar to the others. We observed differentiation by sampling year between 2014 and 2018, and between 2016 and 2018 (figure 3B), suggesting there was a variable influencing the macroinvertebrate assemblages during the study period. 
A)

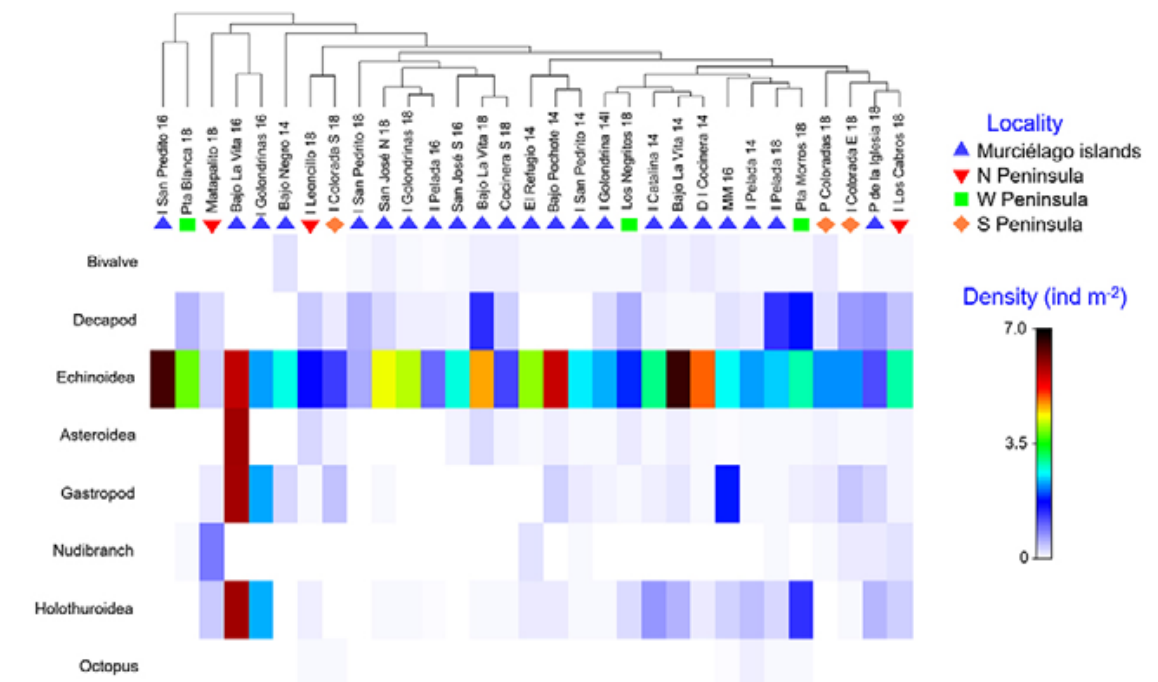

B)

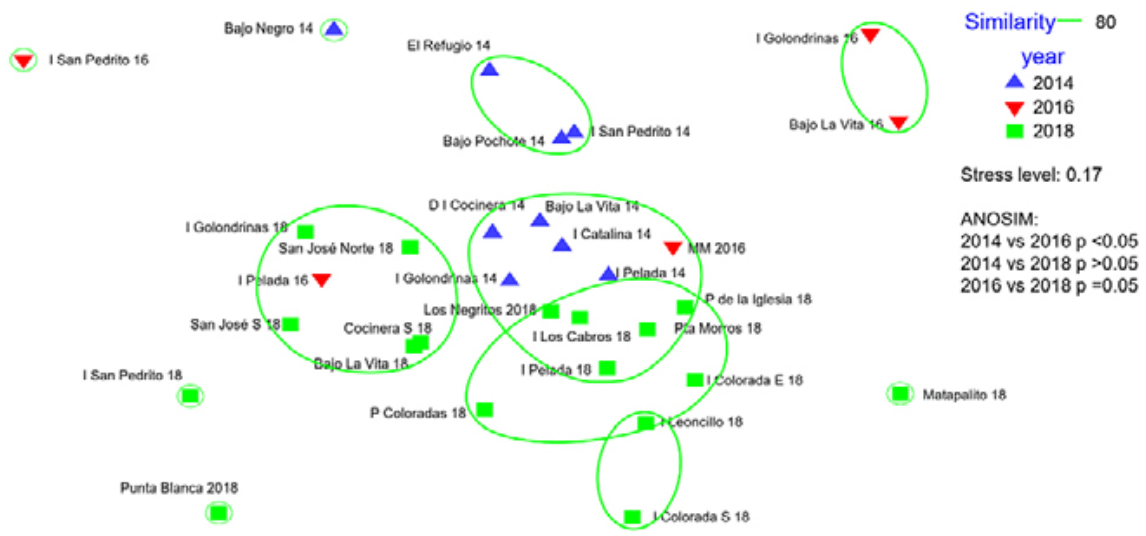

Figure 3. Similarities among localities considering the composition of macroinvertebrate densities (ind $\cdot \mathrm{m}^{-2}$ ) in Murciélago Islands and Santa Elena Peninsula, based on a Bray-Curtis index, using a A) dendrogram and an B) nMDS plot.

\section{Fishes}

We recorded a total of 84 species of fishes, distributed in 20 families and 10 orders. The biomass was dominated by piscivores with the highest mean $( \pm$ standard deviation) biomass of $0.63 \pm 1.01$ ton ha $^{-1}$, followed by macroalgae-eating herbivores $\left(0.39 \pm 1.09\right.$ ton $\left.\cdot h^{-1}\right)$. The detritivores $\left.\left(0.13 \pm 0.17 \text { ton } \cdot h^{-1}\right)^{-1}\right)$, invertebrate feeders $\left(0.10 \pm 0.15\right.$ ton $\left.\cdot \mathrm{ha}^{-1}\right)$, and planktivores $\left(0.07 \pm 0.12\right.$ ton $\left.\cdot \mathrm{ha}^{-1}\right)$ presented intermediate biomass values. The omnivores presented the lowest biomass: $0.01 \pm 0.05$ ton $\cdot \mathrm{ha}^{-1}$. 


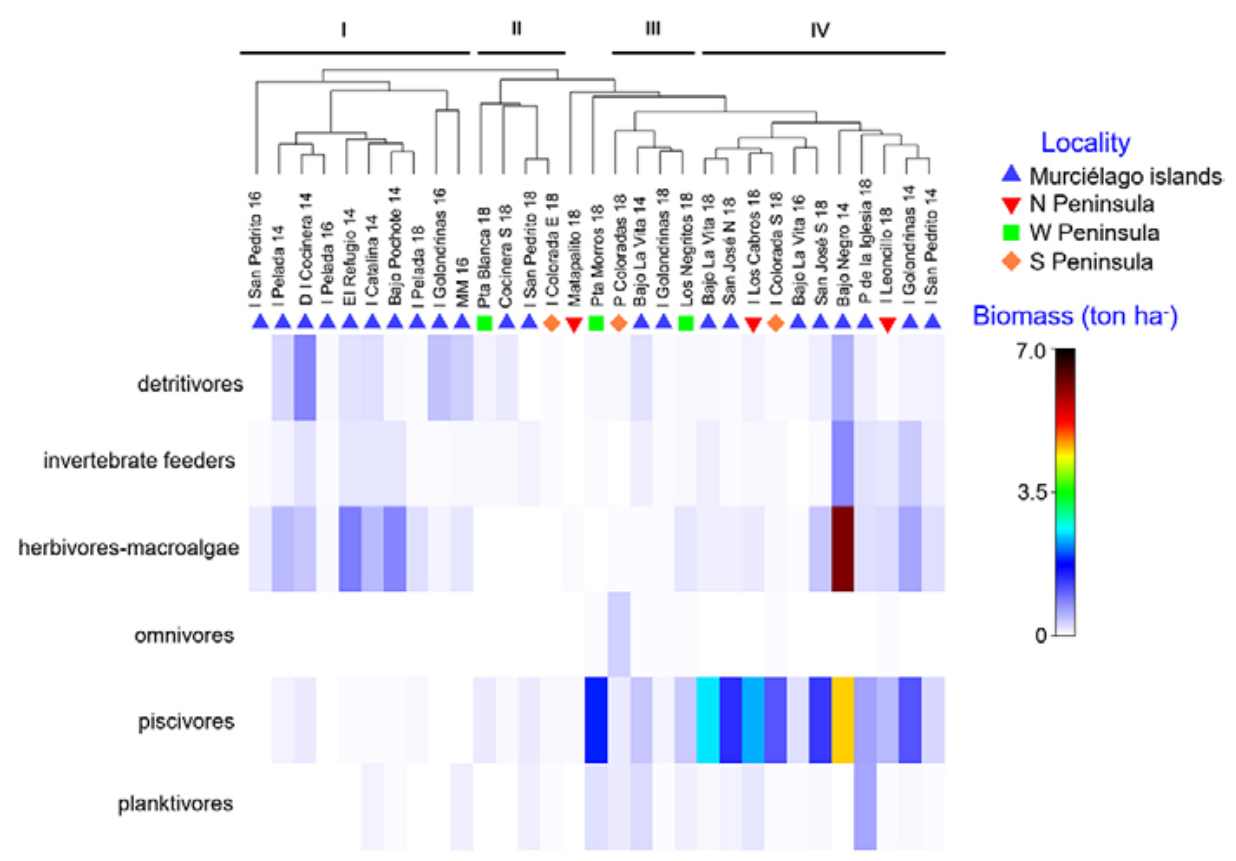

Figure 4. Similarities among localities considering the biomass composition of fishes by functional groups (ton'ha ${ }^{-1}$ ) in Murciélago Islands and Santa Elena Peninsula, based on a Bray-Curtis index.

The results of the ANOSIM of fish assemblages based on the biomass of trophic groups sugessted four main groups of localities. Group I only included MI localities during 2014, 2016 and 2018 (figure 4), where detritivores, invertebrate feeders and herbivores-macroalgae dominated the assemblages, while piscivores were uncommon or rare. Group II included several localities from the four areas (MI, and Northern, Southern and Western SE) only during 2018, where the overall biomass of all trophic groups was low. Groups III and IV included localities from 2014 and 2018, with high to moderate biomass of piscivores, with a relatively low biomass of herbivores-macroalgae in group III. Most localities sampled during 2016 were grouped apart from 2018 (figure 4).

The herbivores-macroalgae made the largest contribution to community similarities during 2014 and 2016 , contributing $28.0 \%$ and $35.77 \%$, respectively (table 1). However, during 2018 piscivores contributed the most to similarities among localities (34.06\%). The similarities within a year among the sampled localities were high $(>70 \%)$, while similarities between years were relatively low $(<35 \%)$. The herbivores-macroalgae played a key role in differentiating between 2014 and 2018, while piscivores had a stronger influence between 2014 and 2016 (32.14\%), and between 2016 and 2018 (32.14\%) (table 1). 


\begin{tabular}{|c|c|c|c|}
\hline \multicolumn{4}{|c|}{$\begin{array}{l}\text { TABLE 1. SIMPER TEST FOR FISH TROPHIC GROUPS CONTRIBUTING TO } \\
\text { SIMILARITIES AMONG LOCALITIES CONSIDERING YEAR AS A FACTOR, } \\
\text { MURCIÉLAGO ISLANDS AND SANTA ELENA PENINSULA }\end{array}$} \\
\hline YEAR & Similarity \% & Trophic group & Contribution \% \\
\hline \multirow{3}{*}{2014} & \multirow{3}{*}{83.25} & Herbivore-macroalgae & 28.0 \\
\hline & & Invertebrate feeder & 22.75 \\
\hline & & Detritivore & 21.48 \\
\hline \multirow{3}{*}{2016} & \multirow{3}{*}{71.05} & Herbivore-macroalgae & 35.77 \\
\hline & & Detritivore & 29.32 \\
\hline & & Invertebrate feeder & 27.27 \\
\hline \multirow{3}{*}{2018} & \multirow{3}{*}{77.27} & Piscivore & 34.06 \\
\hline & & Invertebrate feeder & 19.26 \\
\hline & & Detritivore & 17.62 \\
\hline Year & Similarity \% & Trophic group & Contribution \% \\
\hline \multirow{3}{*}{$2014-2016$} & \multirow{3}{*}{24.14} & Piscivore & 36.05 \\
\hline & & Planktivore & 22.23 \\
\hline & & Detritivore & 18.30 \\
\hline \multirow{3}{*}{$2014-2018$} & \multirow{3}{*}{24.89} & Herbivore-macroalgae & 27.04 \\
\hline & & Planktivore & 18.38 \\
\hline & & Piscivore & 17.91 \\
\hline \multirow{3}{*}{$2016-2018$} & \multirow{3}{*}{35.86} & Piscivore & 32.14 \\
\hline & & Herbivore-macroalgae & 18.97 \\
\hline & & Planktivore & 17.07 \\
\hline
\end{tabular}

\section{DISCUSSION}

\section{REEF BOTTOM}

The live coral cover decreased by almost $95 \%$ in the region during the last decade, from 47.4\% to 2.6\% (Bassey-Fallas 2010; Alvarado et al. 2018; present study). The sharp decline of live coral could be related to several factors, such as El Niño-Southern Oscillation (ENSO) (1997-1998, 2010, 2015-2016), harmful algal blooms (HABs) in the area, inadequate fisheries practices and lack of enforcement of MPAs. The El Niño event of 2015-2016 heavily impacted coral biotopes along the southern Pacific coast of Costa Rica, resulting in a decrease in live coral coverage by up to $75 \%$ (Alvarado et al. 2020). Similarly, reefs along the northern Pacific coast of Costa Rica have suffered some level of deterioration, related to ENSO 
events, HABs, the proliferation of invasive seaweed (Caulerpa sertularioides), high densities of bioeroders (such as sea urchins), a decline in water quality and increase in fishing pressure (Jiménez 2007; Fernández-García et al. 2012; Alvarado 2013; Alvarado et al. 2018). Culebra Bay, located $-40 \mathrm{~km}$ south from MI and SE, has lost live coral coverage during the last decades, from $43.09 \%$ in $1995-1996$ to $1.25 \%$ in 2014-2016, attributed to both natural and anthropogenic causes (Alvarado et al. 2018; Sánchez-Noguera et al. 2018; Arias-Godínez et al. 2019). However, MI and SE differ from other localities from the North Pacific coast of Costa Rica, because they have not been heavily impacted by extensive coastal development that can be seen in Culebra Bay (Sánchez-Noguera 2012). The shoreline and lands at MI and SE are strictly protected within the Guanacaste Conservation Area.

During our three-year study, we only found one healthy coral reef in the study area, located at Matapalito Bay, Northern Peninsula, dominated by Pocillopora corals. Currently, Matapalito holds some level of protection, due to the recent creation of the Santa Elena Bay Marine Management Area in 2018 (Executive Decree No41171-MINAE). However, the identification of Matapalito as the only locality with a coral reef raises awareness of its conservation and management. The Matapalito reef should be protected because it is a shelter for coral reef dependent species and a reservoir of corals, that could help to populate other areas through natural dispersion or to be used as sources of fragments for coral gardening (Mora et al. 2006; Almany et al. 2009; Bridge et al. 2013).

\section{Macroinvertebrates}

The echinoids are the dominate macroinvertebrates at MI and SE, as has also been recorded in other areas of the northern and the southern Pacific coast of Costa Rica (Alvarado et al., 2015; Alvarado et al. 2018). Sea urchins play an important role in reefs as grazers, controlling algae growth, but high densities might result in bioerosion for some reef bottom substrates, such as corals (Alvarado et al. 2012, 2016). Despite the lack of evident negative influence of the high densities of echinoids found at MI and SE, these populations should be regularly surveyed, as high densities of echinoids could be related to inadequate management of marine resources, absence of predators due to overfishing, high availability of food (algae), or intense climate events (Alvarado et al. 2016).

In Culebra Bay, the invertebrates associated with healthy Pocillopora reefs were more diverse after the seasonal upwelling than before it, presumably due to recruitment and settlement during and after the event (Alvarado and VargasCastillo 2012). However, there are echinoid aggregations such as Astropyga pulvinata, with higher abundances between December and April (Alvarado 2008). Since all study sites were sampled between May and July, our observations only recorded variation occurring during the rainy season after the seasonal upwelling. These submarine assemblages should be studied considering the great environmental variation observed in the region, as recommended for intertidal invertebrates as well (Sibaja-Cordero and Cortés 2008; Sibaja-Cordero and García-Méndez 2014; Sibaja- 
Cordero et al. 2014). Our observations should be carefully analyzed considering the seasonality of some species in the region coupled with the seasonal upwelling when the conditions are unfavorable for SCUBA diving and sampling.

Lobsters and sea cucumbers presented low densities; this can be an effect of reef deterioration and fishing pressure. In the North Pacific of Costa Rica, there is a dive fishery that targets both lobsters and sea cucumbers, among other resources. The regulation and enforcement of this fishery is deficient, and there are some illegal and unreported catches (Villalobos-Rojas et al. 2014). Lobsters and sea cucumbers have a high market value (Naranjo-Madrigal 2011; Purcell et al. 2014) that provides an incentive for opportunistic exploitation regardless of the regulations or abundance of the population (Branch et al. 2013). The few occurrences with low densities reported here are the consequence of the effects of overfishing on these resources, which have been discussed in previous studies (Toral-Granda 2008; Naranjo-Madrigal 2011; Alvarado et al. 2013, et al. 2018)

\section{Fishes}

We have recorded a relatively high species richness of fishes inhabiting the reef habitats around MI and SE (84 species). In the Catalinas Islands and Ocotal, south of our study area, a total of 46 species were reported during a short study period (Espinoza \& Salas 2005). In Culebra Bay, Dominici-Arosemena et al. (2005) reported a total of 75 species of 28 families of reef fishes in 1997, when the reefs in that area were in healthy conditions. More recently, Arias-Godínez et al. (2019) indicated the presence of 56 species and 24 families surveyed between 2014-2016 in Culebra Bay, indicating a reduction of over $40 \%$ of reef fish orders between both periods. The higher diversity of reef fishes in MI and SE could be the result of the presence of the MPA (Beita-Jiménez et al. 2019).

The high biomass of piscivores suggests that MI and SE have high productivity where top-down control is probably occurring (Stevenson et al. 2007; Baum \& Worm 2009). These patterns have been observed within MPAs, such as Isla del Coco, Costa Rica (Friedlander et al. 2012; Fourriére et al. 2019). However, the piscivores in MI and SE were represented by medium-sized predatory bony fishes, such as snappers (Lutjanidae) and jacks (Carangidae), and not by large-bodied top predators such as sharks as in Isla del Coco (Friedlander et al. 2012, Fourriére et al. 2019). Fishing pressure can affect large predators before other trophic groups due to life history features that make them vulnerable to extraction, such as low fecundity, late maturity, and long-life cycles, and their absence could be related to fisheries (Goeden 1982; Pauly et al. 1998; Francis et al. 2016). The absence of large predatory fishes (e.g., sharks, groupers) in our study could be related to the fishing pressure influence in the area.

Many fisheries in the region target large-bodied predators, including sharks, billfishes, snappers, croakers, snooks, and groupers; however, decreasing landings of some of these groups have been recorded (Villalobos-Rojas et al. 2014). The northern Pacific coast of Costa Rica has been subjected to fishing pressure 
overall, and illegally within its MPAs, including inadequate management and weak enforcement (Sánchez-Jiménez et al. 2014). In Culebra Bay, large-bodied predators suffered population declines during the last 20 years, while herbivore populations increased in response to lower abundance of predator and higher macroalgae cover (Arias-Godínez et al. 2019). The ACG's marine sector, which includes MI and $\mathrm{SE}$, is subjected to illegal incursions of fishers, and park ranger staff do not have enough resources to enforce the MPA's regulations (M.M. Chavarría, personal communication). Authorities should allocate resources for protecting the MPA and ensure the no-take regulations of the ACG. Moreover, buffer zones should be managed around the no-take areas where responsible fishing regulations should prevail in order to protect the fish populations and other marine resources, as well as the reef ecosystems.

Grunts (Haemulidae) were abundant and dominated the fish assemblages at MI and SE. Their population dynamics probably play an important role in these ecosystems. Grunts control different populations of small invertebrates and fishes while experiencing ontogenetic diet shifts and changes in migration patterns through its life-cycle (De La Morinière et al. 2003). Special focus on the population dynamics of grunts could shed light on our understanding of the reef habitats at MI and SE.

\section{Concluding Remarks}

The reef habitats found at MI and SE are subjected to strong environmental seasonality, influenced by both the dry and rainy seasons and the seasonal coastal upwelling. The biological assemblages inhabiting these reefs are highly dynamic due to this seasonality and the geomorphology of the coast. However, despite this being a three-year study, we only recorded data during the transition from the upwelling to the rainy season and focusing on reef environments due to sea conditions. We suggest that further studies should include samplings during at least three different times during the year, in order to record the variation during the dry season before and during the upwelling, and during the rainy season after the upwelling. We also suggest performing surveys on other coastal habitats found at MI and SE, such as Sargassum forests, sand flats, reefs (formed by polychaetes), and mesophotic environments.

The rocky reefs are highly important to preserve the great marine biodiversity in the region and serve to keep connectivity between the few coral reefs found on the northern Pacific coast of Costa Rica. Protection and management of these rocky reefs are necessary to enhance the ecological processes driving the marine biodiversity. We also highlight the necessity to protect the only coral reef found around, at Matapalito Bay, that can be used as a reservoir of corals to populate other areas through natural dispersion or coral gardening. We strongly suggest that authorities allocate resources to protect the MPA and ensure enforcement of the no-take regulations. 


\section{ACKNOWLEDGEMENTS}

We are grateful to Vicerrectoría de Investigación of the Universidad de Costa Rica, to the BioMar-ACG project and to the Waitt Foundation, for financially supporting this study. We are thankful to J.C. Hernández, L. Chacón, M. Lara, F. Joyce, A. Lara, the Plan B crew, MarViva, the Murciélago Islands rangers and M.M. Chavarría. Sampling permits where provided by MINAE-SINAC, permits: ACG-PI-031-2014, ACG-PI-043-2016 and ACG-PI-022-2018. We are grateful for the suggestions and corrections made by an anonymous reviewer, as well as by $\mathrm{B}$. Chomitz.

\section{AUTHORS' CONTRIBUTION}

Conceptualization: JJA, CFG.

Methodology and field work: all authors.

Data analysis: JJA.

Original draft: JJA, JCA, SM.

Review and edition of the final draft: all authors.

Recibido: mayo de 2020, ACEPTAdo: noviembre de 2021 


\section{REFERENCES}

Alfaro, E.J. and Cortés, J. 2012. Atmospheric forcing of cold subsurface water events in Bahía Culebra, Costa Rica. Rev. Biol. Trop., 60 (Suppl. 2): 173-186.

Almany, G.R., Connolly, S.R., Heath, D.D., Hogan, J.D., Jones, G.P., McCook, L.J., Mills, M., Pressey, R.L. and Williamson, D.H. 2009. Connectivity, biodiversity conservation and the design of marine reserve networks for coral reefs. Coral Reefs, 28: 339-351.

Alvarado, J.J. 2008. Seasonal occurrence and aggregation behavior of the sea urchin Astropyga pulvinata (Echinodermata: Echinoidea) in Bahía Culebra, Costa Rica. Pac. Sci., 62: 579-592.

Alvarado, J.J. 2013. Sobrepoblación de erizos de mar en Bahía Culebra: síntoma de mal estado de conservación. Ambientico, 230-231: 35-41.

Alvarado, J.J. and Vargas-Castillo, R. 2012. Invertebrados asociados al coral constructor de arrecifes Pocillopora damicornis en Playa Blanca, Bahía Culebra, Costa Rica. Rev. Biol. Trop., 60 (Suppl. 2): 77-92.

Alvarado, J.J., Cortés, J. and Reyes-Bonilla, H. 2012. Reconstruction of Diadema mexicanum bioerosion impact on three Costa Rican Pacific coral reefs. Rev. Biol. Trop., 60 (Suppl. 2): $121-132$.

Alvarado, J.J., Barraza, E. and Sancho-Mejía, T. 2013. «Central America Echinoderms: diversity, ecology and future perspectives», in Alvarado, J.J., \& Solís-Marín, F.A., editors. Echinoderm Research and Diversity in Latin America. Berlin, Germany, Springer. pp. 67-106.

Alvarado, J.J., Beita-Jiménez, A., Mena, S., Fernández-García, C. and Guzman, A.G. 2015. Ecosistemas coralinos del Área de Conservación Osa, Costa Rica: análisis estructural y necesidades de conservación. Rev. Biol. Trop., 63 (Supl. 1): 219-259.

Alvarado, J.J., Cortés, J., Guzman, H.M. and Reyes-Bonilla, H. 2016. Bioerosion by the sea urchin Diadema mexicanum along Eastern Tropical Pacific coral reefs. Mar. Ecol., 37: 1088-1102.

Alvarado, J.J., Beita-Jiménez, A., Mena, S., Fernández-García, C., Cortés, J., Sánchez-Noguera, C., Jiménez, C. and Guzmán-Mora, A.G. 2018. Cuando la conservación no puede seguir el ritmo del desarrollo: Estado de salud de los ecosistemas coralinos del Pacífico Norte de Costa Rica. Rev. Biol. Trop., 66: S280-S308.

Alvarado, J.J., Sánchez-Noguera, C., Arias-Godínez, G., Araya, T., Fernández-García, C., and Guzmán-Mora, A.G. 2020. Impact of El Niño 2015-2016 on the coral reefs of the Pacific of Costa Rica: the potential role of marine protection. Rev. Biol. Trop., 68 (S1): S271-S282.

Arias-Godínez, G., Jiménez, C., Gamboa, C., Cortés, J., Espinoza, M. and Alvarado, J.J. 2019. Spatial and temporal changes in reef fish assemblages on disturbed coral reefs, north Pacific coast of Costa Rica. Mar. Ecol. 40: e12532.

Bassey-Fallas, G. 2010. Evaluación ecológica de los arrecifes y comunidades coralinas de las Islas Murciélago y sección norte de la Península de Santa Elena en el Pacífico de Costa Rica [tesis de maestría]. Universidad Nacional, Heredia, Costa Rica. 124 p.

BAUM, J.K. and Worm, B. 2009. Cascading top-down effects of changing oceanic predator abundances. Journal of Animal Ecology, 78: 699-714. 
Beebe, W. 1938. Eastern Pacific expeditions of the New York Zoological Society, XIv. Introduction, itinerary, list of stations, nets and dredges of the eastern Pacific Zaca expedition, 19371938. Zoologica, 23: 287-298.

Beita-Jiménez, A., Alvarado, J.J., Mena, S. and Guzmán-Mora, A.G. 2019. Benefits of protection on reef fish assemblages in a human impacted region in Costa Rica. Ocean Coast. Manag., 169: 165-170.

Branch, T.A., Lobo, A.S. and Purcell, S.W. 2013. Opportunistic exploitation: an overlooked pathway to extinction. Trends Ecol. Evol. 28: 409-413.

Bridge, T.C., Hughes, T.P., Guinotte, J.M. and Bongaerts, P. 2013. Call to protect all coral reefs. Nature Climate Change, 3: 528-530.

Clarke, K.R. and Gorley, R.N. 2006. PRIMER v6: User manual. PRIMER-E Ltd, Plymouth, U.K.

Cortés, J. 1996-1997. Comunidades coralinas y arrecifes del Área de Conservación Guanacaste, Costa Rica. Rev. Biol. Trop., 44/45: 623-625.

Cortés, J. 2014. Compilación y análisis de las investigaciones científicas sobre temas marinos y atmosféricos en el Pacífico Norte de Costa Rica. Rev. Biol. Trop., 62 (Supl. 4): 151-184.

Cortés, J. 2017. Marine biodiversity baseline for Área de Conservación Guanacaste, Costa Rica: published records. ZooKeys, 652: 129-179.

Cortés, J. and Jiménez, C. 2003. Corals and coral reefs of the Pacific of Costa Rica: history, research and status. In Cortés, J., editor. Latin American Coral Reefs. Amsterdam, Elsevier Science. pp. 361-385.

Cortés, J. and Joyce, F. 2020. BioMar-ACG: A successful partnership to inventory and promulgate marine biodiversity. Biotropica, 52: 1104-1107.

Cortés, J., Jiménez, C.E., Fonseca, A.C. and Alvarado, J.J. 2010. Status and conservation of coral reefs in Costa Rica. Rev. Biol. Trop., 58 (Suppl. 1): 33-50.

Cortés, J., Samper-Villarreal, J. and Bernecker, A. 2014. Seasonal phenology of Sargassum liebmannii J. Agardh (Fucales, Heterokontophyta) in an upwelling area of the Eastern Tropical Pacific. Aqua. Bot., 119: 105-110.

Crocker, T. 1933. The Templeton Crocker Expedition of the California Academy of Sciences, 1932, No. 2: Introductory statement. Proc. Cal. Acad. Sci., 4:3-9.

De la Mornière, E.C., Pollux, B.J.A., Nagelkerken, I. and Van der Velde, G. 2003. Diet shifts of Caribbean grunts (Haemulidae) and snappers (Lutjanidae) and the relation with nursery-to-coral reef migrations. Estuar. Coast. Shelf Sci., 57: 1079-1089.

Denyer, P. 2009. Perspectiva geológica del noroeste de Costa Rica: Historia, evolución y cartografía. Editorial UCR, San Pedro, Costa Rica. 347 p.

Denyer, P. and Gazel, E. 2009. The Costa Rican Jurassic to Miocene oceanic complexes: Origin, tectonics and relations. J. South Am. Earth Sci., 28: 429-442.

Denyer, P., Cortés, J. and Cárdenes, G. 2005. Hallazgo de dunas fósiles de final del pleistoceno en las Islas Murciélago, Costa Rica. Rev. Geol. Am. Centr., 33: 29-44.

Dominici-Arosemena, A., Brugnoli-Olivera, E., Cortés-Nuñez, J., Molina-Ureña, H. and Quesada-Alpízar, M. 2005. Community structure of eastern Pacific reef fishes (Gulf of Papagayo, Costa Rica). Tecnociencia, 7: 19-41.

Espinoza, M. and Salas, E. 2005. Estructura de las comunidades de peces de arrecife en las Islas Catalinas y Playa Ocotal, Pacífico Norte de Costa Rica. Rev. Biol. Trop., 53: 523-536. 
Fernández-García, C., Cortés, J., Alvarado, J.J. and Nivia-Ruíz, J. 2012. Physical factors contributing to the benthic dominance of the alga Caulerpa sertularioides (Caulerpaceae, Chlorophyta) in the upwelling Bahía Culebra, north Pacific of Costa Rica. Rev. Biol. Trop., 60 (Suppl. 2): 93-107.

Fourriére, M., Alvarado, J.J., Cortés, J., Taylor, M.H., Ayala-Bocos, A., Azofeifa-Solano, J.C., Arauz, R., Heidemeyer, M., López-Garro, A., Zanella, I. and Wolff, M. 2019. Energy flow structure and role of keystone groups in shallow water environments in Isla del Coco, Costa Rica, Eastern Tropical Pacific. Ecol. Mod., 396: 74-85.

Francis, M.P., Harasti, D. and Malcolm, H.A. 2016. Surviving under pressure and protection: a review of the biology, ecology and population status of the highly vulnerable grouper Epinephelus daemelii. Mar. Fresh. Res., 67: 1215-1228.

Friedlander, A., Zgliczynski, B.J., Ballesteros, E., Aburto-Oropeza, O., Bolaños, A. and SALA, E. 2012. The shallow-water fish assemblage of Isla del Coco National Park, Costa Rica: structure and patterns in an isolated, predator-dominated ecosystem. Rev. Biol. Trop., 60 (Suppl. 3), 321-338.

Goeden, G.B. 1982. Intensive fishing and a 'keystone'predator species: ingredients for community instability. Biol. Conser., 22: 273-281.

Hauff, F., Hoernle, K. and Bogaard, P. 2000. Age and geochemistry of basaltic complexes in western Costa Rica: Contributions to the geotectonic evolution of Central America. Geochem. Geophys. Geosyst., 1, 1009, doi:10.1029/1999GC000020.

Janzen, D.H. 1998. Conservation analysis of the Santa Elena property, Peninsula Santa Elena, northwestern Costa Rica. Univ. Pennsylvania, Philadelphia. 129 p.

Jiménez, C. 2007. Arrecifes coralinos, ¿̨í́ctimas de los cambios? Ambientico, 171: 5-7.

Jiménez, C., Cortés, J., León, A. and Ruíz, E. 2001. Coral bleaching and mortality associated with the 1997-98 El Niño in an upwelling environment in the eastern Pacific (Gulf of Papagayo, Costa Rica). Bull. Mar. Sci., 69: 151-169.

Lizano, O.G. and Alfaro, E.J. 2014. Características de la dinámica atmosférica y oceánica en algunas regiones del Área de Conservación Guanacaste (ACG), Costa Rica. Rev. Biol. Trop., 62 (Supl. 4): 17-31.

McCauley, D.J., Joyce, F.J. and Lowenstein, J.H. (2008). Effects of the aquarium fish industry in Costa Rica on populations of the Cortez rainbow wrasse Thalassoma lucasanum. Cien. Mar., 34: 445-451.

Mora, C., Andrèfouët, S., Costello, M.J., Kranenburg, C., Rollo, A., Veron, J. Gaston, K.J. and Myers, R.A. 2006. Coral Reefs and the Global Network of Marine Protected Areas. Science, 312: 1750-1751

Naranjo-Madrigal, H. 2011. Biología pesquera de la langosta Panulirus gracilis en Playa Lagarto, Guanacaste, Costa Rica. Rev. Biol. Trop. 59(2): 619-633.

Pauly, D., Christensen, V., Dalsgatad, J. Froese, R. and Torres, F. 1998. Fishing down marine food webs. Science, 279: 860-863.

Purcell, S.W., Polidoro, B.A., Hamel, J.F., Gamboa, R.U. and Mercier, A. 2014. The cost of being valuable: predictors of extinction risk in marine invertebrates exploited as luxury seafood. Proc. Royal Soc. B: Biol. Sci. 281: 20133296. 
Quimbayo, J.P., Mendes, T.C., Kulbicki, M., Floerter, S.R. and Zapata, F.A. 2017. Unusual reef fish biomass and functional richness at Malpelo, a remote island in the Tropical Eastern Pacific. Environ. Biol. Fish., 100: 149.

Sánchez-Jiménez, A., Morales-Ramírez, A., Samper-Villarreal, J. and Sánchez-Noguera, C. 2014. Percepción comunitaria y procesos de Gestión Integrada de Zonas Costeras en el Pacífico Norte de Costa Rica. Rev. Biol. Trop., 62 (Suppl. 4) 139-149.

Sánchez-Noguera, C. 2012. Entre historias y culebras: más que una bahía (Bahía Culebra, Guanacaste, Costa Rica). Rev. Biol. Trop., 60 (Suppl. 2): 01-17.

Sánchez-Noguera, C., Jiménez, C. and Cortés, J. 2018. Desarrollo costero y ambientes marino-costeros en Bahía Culebra, Guanacaste, Costa Rica. Rev. Biol. Trop., 66 (Suppl. 1): S309-S327.

Sibaja-Cordero, J.A. and Cortés, J. 2008. Vertical zonation of rocky intertidal organisms in a seasonal upwelling area (Eastern Tropical Pacific). Rev. Biol. Trop. 56 (Suppl. 4): 91-104.

Sibaja-Cordero, J.A. and García-Méndez, K. 2014. Variación espacial y temporal de los organismos de un intermareal rocoso: Bahía Panamá, Pacífico Norte, Costa Rica. Rev. Biol. Trop., 62 (Suppl. 4): 85-97.

Sibaja-Cordero, J.A., Camacho-García, Y.E. and\& Vargas-Castillo, R. 2014. Riqueza de especies de invertebrados en playas de arena y costas rocosas del Pacífico Norte de Costa Rica. Rev. Biol. Trop., 62 (Suppl. 4): 63-84.

Stevenson, C., Katz, L.S., Micheli, F., Block, B., Heiman, K.W., Perle, C., Weng, K., Dunbar, R. and Witting, J. 2007. High apex predator biomass on remote Pacific islands. Coral Reefs, 26: 47-51.

Toral-Granda, V. 2008. "Population status, fisheries and trade of sea cucumbers in Latin America and the Caribbean," in Toral-Granda, V., Lovatelli, A., \& Vasconcellos, M., editors. Sea cucumbers. A global review of fisheries and trade. FAO Fisheries and Aquaculture Technical Paper. No. 516. Rome, FAO. P 213-229.

Villalobos-Rojas, F., Herrera-Correal, J., Garita-Alvarado, C.A., Clarke, T. and BeitaJiménez, A. 2014. Actividades pesqueras dependientes de la ictiofauna en el Pacífico Norte de Costa Rica. Rev. Biol. Trop., 62 (Suppl. 4): 119-137. 
